\title{
De effecten van other-benefit appeals, self-benefit appeals en exemplars bij het werven van vrijwilligers voor charitatieve organisaties
}

\section{Inleiding: vrijwilligers werven}

In Nederland strijden enkele duizenden charitatieve organisaties met elkaar om steun van de gulle gever. In die strijd neemt de wervingsbrief nog steeds een belangrijke plaats in (zie Hoeken \& Hustinx, 2007). De mogelijkheid om met dergelijke brieven vrijwilligers en donaties te werven, maakt de vraag relevant naar wat de effectiviteit van deze brieven bepaalt. Het steunen van het doel van de wervingsbrief levert voordelen op voor een specifieke doelgroep. Zo laten de CliniClowns zieke kinderen hun angsten en ziekte tijdelijk vergeten en zorgen vrijwilligers van Nationale Vereniging de Zonnebloem ervoor dat mensen met een fysieke beperking in contact blijven met de maatschappij. Omdat vrijwilligers met hun werk anderen helpen, wordt vrijwilligerswerk wel gezien als een daad van opoffering waaraan geen persoonlijk gewin verbonden is (Handy, Cnaan, Brudney, Ascoli, Meijs, \& Ranade, 2000). Maar vrijwilligerswerk creëert wel degelijk ook voordelen voor de vrijwilliger zelf, zoals positieve gevoelens en een goede gezondheid (Wilson, 2000). Hulpgedrag, zoals vrijwilligerswerk, kan dus zowel positieve gevolgen voor anderen als positieve gevolgen voor de vrijwilliger zelf hebben. Vanwege deze twee motieven voor hulpgedrag richten tekstschrijvers hun brieven dan ook op voordelen voor de hulpbehoevenden (other-benefit) of voor de lezer (self-benefit). In onderzoek is het inspelen op de

\section{Samenvatting}

In onderzoek naar de effectiviteit van wervingsbrieven is het inspelen op de belangen voor een ander (other-benefit appeal) regelmatig vergeleken met het inspelen op de belangen voor de lezer zelf (self-benefit appeal). Omdat bij deze vergelijkingen de belangen inhoudelijk van elkaar verschilden, zijn in het huidige onderzoek de voordelen van gepropageerd gedrag in alle condities gelijkgehouden. Hiertoe werden exemplars ingezet. Wervingsbrieven met een exemplar werden tevens vergeleken met wervingsbrieven zonder exemplar om de effecten van exemplars na te gaan. Een experiment werd uitgevoerd met een 2 (type appeal) $\mathrm{x}$ 2 (met exemplar/zonder exemplar) tussenproefpersoonontwerp $(N=120)$. De other-benefit appeal bleek overtuigender te zijn dan de selfbenefit appeal. Brieven met een exemplar waren weliswaar niet overtuigender dan brieven zonder exemplar, maar werden wel beter gewaardeerd. Dit effect werd volledig gemedieerd door de levendigheid en de begrijpelijkheid van de brief. 
other-benefit vaak, maar zeker niet altijd, overtuigender gebleken. Een mogelijke verklaring voor dit effect ligt deels wellicht in de onzuivere vergelijking van beide appeals. Zo zijn de voordelen voor anderen vaak zeker (bv. dankzij uw donatie zal een patiënt medicijnen krijgen) en treden ze op korte termijn op. Of het eigen voordeel ooit op gaat treden (bv. als $\mathrm{u}$ zelf patiënt van deze ziekte wordt, zal u dankzij uw donatie medicijnen krijgen), is vaak maar de vraag.

Dit artikel legt verslag van een experiment waarin de twee soorten appeals zijn vergeleken in een brief gericht op het werven van vrijwilligers. In de manipulatie is nadrukkelijk rekening gehouden met de zekerheid en termijn van de voordelen. Dit is onder andere gedaan door de inzet van exemplars, korte voorbeeldgeschiedenissen van in dit geval een vrijwilliger en een patiënt. Deze inzet geeft de extra mogelijkheid om de effecten van exemplars te onderzoeken. Waar vorig onderzoek met name soorten exemplars met elkaar vergelijkt (onder andere Gibson \& Zillmann, 1994; Hoeken \& Hustinx, 2007), zijn hier brieven met en zonder exemplars vergeleken. Op die manier levert deze studie zowel een bijdrage aan het debat over appeals in wervingsbrieven als aan onderzoek naar de effectiviteit van exemplars.

\section{Hulpgedrag: motieven en appeals}

Over de motieven die ten grondslag liggen aan hulpgedrag bestaat al decennialang debat. De empathy-altruism-hypothese (Batson, Duncan, Ackerman, Buckley, \& Birch, 1981) voorspelt dat mensen anderen helpen vanuit altruïstische motieven. Centraal in de theorievorming over altruïstisch gemotiveerd gedrag staat het menselijk vermogen om te geven om anderen (Batson, 1990). Gevoelens van empathie voor een ander zorgen ervoor dat het doel van hulpgedrag bestaat uit het verbeteren van de leefsituatie van diegene; egoïstische belangen spelen hierbij geen rol.Verschillende onderzoeken hebben aangetoond dat hulpgedrag, zoals het verrichten van vrijwilligerswerk (Unger, 1991) en het doneren van geld aan een goed doel (Eckel \& Grossman, 1996), inderdaad voortkomt uit altruïsme. Met een reeks experimenten is tevens de relatie tussen empathie en altruïsme aangetoond, waardoor ondersteuning is gevonden voor de empathy-altruism-hypothese (Batson, Dyck, Brandt, Batson, Powell, McMaster, \& Griffitt, 1988; Batson, Batson, Slingsby, Harrell, Peekna, \& Todd, 1991).

Lijnrecht tegenover de empathy-altruism-hypothese (Batson et al., 1981) staat de Social Exchange Theory (Blau, 1964). Deze theorie gaat uit van de egoïstische belangen van de mens en stelt dat mensen investeringen doen op basis van een balans tussen de verwachte kosten en baten van een investering. Het verrichten van vrijwilligerswerk kan bijvoorbeeld de gezondheid van de vrijwilliger verbeteren (Wilson, 2000) maar legt tegelijkertijd beslag op de vrije tijd van de vrijwilliger.Volgens de Social Exchange Theory (Blau, 1964) zal iemand alleen hulpgedrag vertonen indien de persoonlijke voordelen daarvan groter worden geacht dan de kosten; indien echter verwacht wordt dat de voordelen niet opwegen tegen de kosten, zal dit hulpgedrag uitblijven. Verschillende onderzoeken hebben aangetoond dat mensen zich bij het doneren van geld inderdaad laten leiden door egoïstische motieven (bv. Landry, Lange, List, Price, \& Rupp, 2006). Daarnaast geven vrijwilligers vaak egoïstische redenen voor het werk dat zij verrichten, waaronder het opdoen van werkervaring en het verhogen van hun sociale status (zie Piliavin \& Charng, 1990).

De grondideeën uit de empathy-altruism-hypothese (Batson et al., 1981) en de Social Exchange Theory (Blau, 1964) zijn zichtbaar in de manier waarop charitatieve organisaties men- 
sen proberen over te halen tot het bieden van hulp. In wervingsbrieven wordt regelmatig geappelleerd aan de altruistische of de egoïstische motieven van mensen om te doneren (White \& Peloza, 2009). Enerzijds kan met een other-benefit appeal worden ingespeeld op altruïstische motieven door de voordelen te benadrukken die een donatie zou hebben voor anderen, zoals Ferguson, Farrell en Lawrence (2008, p. 333) in hun onderzoek hebben gedaan:

Door bloed te doneren bevorder je de behandeling van patiënten die herstellen van ziektes zoals leukemie, kanker, sikkelcelziekte en thalassemie.

Anderzijds kan met een self-benefit appeal worden ingespeeld op egö̈stische motieven door de voordelen te benadrukken die een donatie zou hebben voor de donateur zelf, bijvoorbeeld (Ferguson et al., 2008, p. 333):

Door bloed te doneren kun je je tevreden, voldaan, gelukkig en trots op jezelf voelen.

De besproken theorieën over de motieven van hulpgedrag maken verschillende voorspellingen mogelijk over de effectiviteit van beide soorten appeals. Op basis van de empathy-altruismhypothese (Batson et al., 1981) kan voorspeld worden dat wervingsbrieven het meest effectief zijn indien gebruikgemaakt wordt van other-benefit appeals, omdat dergelijke appeals de lezers wijzen op de mogelijkheid om hun gevoelens van empathie om te zetten in gedrag dat het leven van een ander zal verbeteren. De Social Exchange Theory (Blau, 1964) ondersteunt juist de gedachte dat self-benefit appeals effectiever zouden zijn omdat zulke appeals benadrukken dat een donatie ook voordelen voor de lezer zelf kan hebben.

Onderzoek naar de relatieve invloed van beide soorten appeals heeft tot gemengde resultaten geleid. Zo zijn toegewijde bloeddonoren eerder bereid bloed te doneren na het lezen van een self-benefit appeal (Ferguson et al., 2008), terwijl other-benefit appeals succesvoller zijn in het werven van donaties voor een publiek televisiestation (Fisher,Vandenbosch, \& Antia, 2008). Bij het werven van donaties voor een goed doel blijken self-benefit appeals in de vorm van een aangeboden product in ruil voor een donatie juist effectiever te zijn dan other-benefit appeals (Holmes, Miller, \& Lerner, 2002). Het relatieve effect van de twee typen appeals is tevens afhankelijk van demografische, culturele en contextuele factoren. Amerikaanse mannen blijken een voorkeur te hebben voor self-benefit appeals, terwijl Amerikaanse vrouwen otherbenefit appeals prefereren (Brunel \& Nelson, 2000). Voor vrouwen in masculiene culturen en mannen in feminiene culturen zijn other-benefit appeals overtuigender, maar voor mannen in masculiene culturen en vrouwen in feminiene culturen zijn self-benefit appeals overtuigender (Nelson, Brunel, Supphellen, \& Manchanda, 2006). In Nederland, dat een feminiene cultuur kent, blijken other-benefit appeals juist voor zowel mannen als vrouwen overtuigender te zijn dan self-benefit appeals (Hornikx, Hendriks, \& Thijzen, 2010). Ten slotte heeft een reeks experimenten laten zien dat self-benefit appeals overtuigender zijn indien de keuze om wel of niet te doneren privé blijft, terwijl other-benefit appeals overtuigender zijn indien de keuze om wel of niet te doneren geopenbaard zal worden aan anderen (White \& Peloza, 2009).

In de meeste onderzoeken blijkt de other-benefit appeal overtuigender te zijn, wat niet vreemd is omdat hulpgedrag in de eerste plaats gericht is op de hulpbehoevende(n).Veel van de onderzoeken naar de relatieve overtuigingskracht van other-benefit appeals en self-benefit appeals kampen echter met een probleem dat de interpretatie van de gevonden resultaten bemoeilijkt: de voordelen voor de ander die genoemd worden in de other-benefit appeal ver- 
tonen sterke afwijkingen van de voordelen voor de donateur die genoemd worden in de self-benefit appeal. In de eerste plaats hebben de voordelen voor de ander zoals die genoemd worden in other-benefit appeals vaak betrekking op gezondheidsaspecten (bijvoorbeeld op de ontwikkeling en verspreiding van medicijnen), terwijl de voordelen voor de donateur zelf zoals die genoemd worden in de self-benefit appeals vaak betrekking hebben op geheel andere aspecten (bijvoorbeeld op gevoelens of persoonlijke vorming).

In de tweede plaats, en veel belangrijker, verschillen de appeals regelmatig van elkaar in de mate van zekerheid dat en termijn waarop het gevolg van een donatie ook daadwerkelijk zal optreden.Voor other-benefit appeals geldt in de regel dat een donatie zeker en vrijwel direct leidt tot een voordeel voor anderen: met gedoneerd geld worden patiënten behandeld, met gedoneerd bloed worden levens gered, en met hun gedoneerde tijd zorgen vrijwilligers ervoor dat de leefsituatie van hulpbehoevenden verbetert. De voordelen voor de donateur die genoemd worden in self-benefit appeals zijn vaak minder zeker en betreffen een langere termijn. Er wordt bijvoorbeeld gesuggereerd dat de lezer ooit zelf een bloedtransfusie nodig zou kunnen hebben en daarom nu alvast bloed zou moeten doneren (Hupfer, 2006), of dat de lezer in de toekomst wellicht een ziekte krijgt en door nu geld te doneren, later beter geholpen kan worden (Hornikx et al., 2010). Deze toekomstscenario's zijn onzeker en daardoor is het voor de lezer ook niet zeker of een donatie daadwerkelijk zal leiden tot een persoonlijk voordeel.Van de genoemde onderzoeken naar de relatieve overtuigingskracht van other-benefit appeals en self-benefit appeals is geïnventariseerd of de voordelen zeker op relatief korte termijn zouden plaatsvinden of dat het onzeker was of deze überhaupt wel zouden optreden. De uitkomsten van deze inventarisatie staan in tabel 1.

Tabel 1: Zekerheid van de voordelen van een donatie in de other-benefit appeals en self-benefit appeals uit eerdere onderzoeken

\begin{tabular}{|c|c|c|}
\hline Type appeal & $\begin{array}{l}\text { Voordeel donatie } \\
\text { treedt zeker op }\end{array}$ & treedt mogelijk later op \\
\hline Other-benefit appeal & $\begin{array}{l}10 \\
\text { Brunel \& Nelson (2000, 2003; studies } \\
\text { hebben identiek materiaal), Ferguson et } \\
\text { al. (2008), Fisher et al. (2008), Holmes et } \\
\text { al. (2002), Hornikx et al. (2010), Hupfer } \\
\text { (2006), Nelson et al. (2006), White \& } \\
\text { Peloza (2009; studie 1-3 [studies hebben } \\
\text { identiek materiaal]; studie 4; studie 5) }\end{array}$ & 0 \\
\hline Self-benefit appeal & $\begin{array}{l}6 \\
\text { Ferguson et al. (2008), Fisher et al. (2008), } \\
\text { Holmes et al. (2002), White \& Peloza } \\
\text { (2009; studie 1-3 [studies hebben identiek } \\
\text { materiaal]; studie 4; studie 5) }\end{array}$ & $\begin{array}{l}4 \\
\text { Brunel \& Nelson }(2000,2003), \text { Hornikx } \\
\text { et al. (2010), Hupfer (2006), Nelson et al. } \\
\text { (2006) }\end{array}$ \\
\hline
\end{tabular}

Tabel 1 laat zien dat het optreden van de voordelen van een donatie in de gemanipuleerde other-benefit appeals altijd zeker is, terwijl de voordelen van een donatie in de gemanipuleerde self-benefit appeals in vier van de tien gevallen slechts mogelijk later optreden en dus niet gegarandeerd zijn. Wellicht is de overtuigingskracht van de other-benefit appeal voor een deel wel te verklaren doordat daarin altijd wordt ingespeeld op zekere voordelen op relatief korte termijn. Dit verschil in de manipulatie van de appeals maakt vergelijkingen tussen hun effecten onzuiver. Om tot betere inzichten in de effectiviteit van beide typen appeals in wer- 
vingsbrieven te komen, is het van belang dat de appeals op gecontroleerde wijze met elkaar vergeleken worden. De volgende onderzoeksvraag is daarom opgesteld:

Onderzoeksvraag 1: Wat is het effect van self-benefit appeals en other-benefit appeals op de overtuigingskracht van wervingsbrieven van charitatieve organisaties indien de zekerheid dat en de termijn waarop de voordelen in beide appeals optreden gelijk zijn?

Een manier om de voordelen gelijk te houden in other-benefit appeals en self-benefit appeals, is het gebruik van een exemplar.

\section{Exemplars}

Exemplars zijn korte voorbeeldgeschiedenissen die aan de hand van het verhaal van één persoon de situatie van een grotere groep mensen illustreren (Zillmann, 2006).Van exemplars wordt gedacht dat ze een tekst levendig en begrijpelijk maken (Brosius, 1999). Deze levendigheid en begrijpelijkheid zijn voor journalisten redenen om hun artikelen van dit soort persoonlijke verhalen te voorzien (Hinnant, Len-Ríos, \& Young, 2012). Ook in persuasieve teksten wordt veelvuldig gebruik gemaakt van exemplars (Zillmann \& Brosius, 2000). Hoewel onderzoeken meestal rapporteren dat bewijs op basis van één geval (exemplar) minder overtuigend is dan bewijs op basis van grotere aantallen gevallen (zie overzichten Hornikx, 2005, 2007), lijkt de exemplar ook effectief in het beïnvloeden van oordelen. Exemplars kunnen inderdaad van grote invloed zijn op de overtuigingen van de lezers over de werkelijkheid, omdat lezers de informatie uit exemplars als representatief zien (Gibson \& Zillmann, 1994): wat voor de persoon uit de exemplar geldt, zal voor andere mensen in een vergelijkbare situatie ook gelden.

De effecten van exemplars op de overtuigingen van de lezer kunnen worden verklaard aan de hand van een aantal heuristieken. De representativiteitsheuristiek houdt in dat mensen aan de hand van voorbeelden een representatief beeld van de werkelijkheid vormen, en zich bij het vormen van een oordeel baseren op de kennis uit die voorbeelden (Zillmann, 2006; Kahneman, 2003). De beschikbaarheidsheuristiek houdt in dat mensen hun oordeel eerder laten bepalen door informatie die beter te onthouden is dan informatie die minder goed te onthouden is. Een sensationeel, levendig verhaal wordt makkelijker onthouden dan statistische cijfers. Zodra mensen ergens een oordeel over gaan vormen, komt informatie in de vorm van voorbeeldverhalen daarom eerder in gedachten dan statistische informatie (Kahneman, 2003). Als levendige voorbeeldverhalen profiteren exemplars van de inzet van de representativiteitsheuristiek en de beschikbaarheidsheuristiek door de lezer wanneer deze zijn overtuigingen over de werkelijkheid vormt.

Onderzoek naar de effecten van other-benefit appeals en self-benefit appeals in wervingsbrieven kan gebruik maken van exemplars om de voordelen van een donatie in beide appeals van gelijke zekerheid te voorzien, omdat een exemplar voor lezers - die de representativiteitsheuristiek toepassen - het bewijs kan zijn dat een donatie in het algemeen bepaalde voordelen tot gevolg heeft. Een other-benefit appeal in de vorm van een exemplar van iemand die dankzij de vrijwillige inzet van anderen geholpen is, kan bij de lezer tot de overtuiging leiden dat met vrijwilligerswerk altijd een ander geholpen wordt. Een self-benefit appeal in de vorm van 
een exemplar van een vrijwilliger die voordeel heeft gehad van zijn werk, kan juist tot de overtuiging leiden dat elke donatie een voordeel voor de vrijwilliger tot gevolg heeft. In eerdere onderzoeken ontbrak het de lezer vaak aan de zekerheid dat een donatie (in tijd of geld) voor de lezer zelf gevolgen zou hebben. In dit onderzoek wordt de relatieve effectiviteit van de twee typen appeals daarom onderzocht met behulp van exemplars.

In veel onderzoeken naar de effecten van exemplars worden inhoudelijk afwijkende exemplars met elkaar vergeleken zonder dat er sprake is van een controletekst zonder exemplar. Uitzonderingen zijn de onderzoeken van Aust en Zillmann (1996) en Oliver, Dillard, Bae en Tomul (2012). Aust en Zillmann (1996) vergeleken de effecten van nieuwsberichten over sociale problemen met exemplars over geëmotioneerde en niet-geëmotioneerde personen met nieuwsberichten zonder exemplar. Uit deze studie bleek onder andere dat nieuwsberichten met een exemplar over een geëmotioneerd persoon tot negatievere gevoelens en een grotere perceptie van het probleem leiden dan nieuwsberichten zonder exemplar. Het onderzoek van Oliver et al. (2012) liet zien dat een journalistieke tekst over gestigmatiseerde groepen met een exemplar tot een positievere attitude en gedragsintentie van de lezer leidde dan diezelfde tekst zonder exemplar. Voor journalistieke teksten geldt dus dat exemplars de overtuigingen van de lezer kunnen beïnvloeden en zelfs de overtuigingskracht kunnen vergroten, hoewel dit niet het primaire doel van dit soort teksten is. In onderzoek naar de effectiviteit van exemplars in teksten met een duidelijk persuasief doel worden twee inhoudelijk van elkaar verschillende exemplars met elkaar vergeleken, maar blijft een controleconditie zonder exemplar vaak achterwege (onder andere Hoeken \& Hustinx, 2007; Jansen, Croonen \& De Stadler, 2005). Het is dan ook nog onduidelijk in hoeverre exemplars zelf, los van hun inhoudelijke kenmerken, de overtuigingskracht van persuasieve teksten zoals wervingsbrieven kunnen beïnvloeden. De volgende onderzoeksvraag is daarom opgesteld:

Onderzoeksvraag 2: Makt het toevoegen van een exemplar wervingsbrieven van charitatieve organisaties overtuigender?

Exemplars zijn concrete voorbeelden die voor de lezer makkelijk te verwerken zijn (Zillmann, 2006). Concrete informatie maakt een tekst interessanter (Sadoski, Goetz, \& Rodriquez, 2000) en daarom wordt verwacht dat wervingsbrieven met een exemplar beter gewaardeerd worden dan wervingsbrieven zonder exemplar. Exemplars maken een tekst daarnaast levendig en begrijpelijk (Brosius, 1999; Hinnant et al., 2012). Verwacht wordt dat deze levendigheid en begrijpelijkheid het effect van exemplars op de waardering voor de brief kunnen verklaren. De volgende hypotheses zijn opgesteld:

H1: Wervingsbrieven met een exemplar worden beter gewaardeerd dan wervingsbrieven zonder exemplar

H2: Levendigheid en begrijpelijkheid mediëren het effect van de exemplar op de waardering voor de brief 
Om de onderzoeksvragen te beantwoorden en de hypotheses te toetsen, is een experiment uitgevoerd met een 2 (type appeal) x 2 (exemplar/geen exemplar) tussenproefpersoonontwerp.

4.1 Materiaal Het materiaal bestond uit een brief die diende om vrijwilligers te werven (zie bijlage 1 voor een volledige versie van de brief). De afzender was een fictieve charitatieve organisatie (het Spierziekte Fonds), zodat bestaande attitudes en eventuele eerdere donaties niet van invloed konden zijn op de resultaten. De keuze voor spierziektes, waarvan de meeste doorgaans geen acuut levensgevaar opleveren, kon er bovendien voor zorgen dat de brief zelf, en niet de ernst van de ziekte, mogelijke effecten op de lezer kon verklaren. In brieven waarin levensbedreigende ziektes centraal staan kunnen tekstuele manipulaties hun effecten op de lezer namelijk verliezen, omdat lezers in dat geval hoe dan ook bereid zijn hulp te bieden (cf. Hoeken \& Hustinx, 2007, experiment 3). In de brief stond vrijwilligerswerk bij het Spierziekte Fonds centraal. Uitgelegd werd dat het Spierziekte Fonds met de hulp van vrijwilligers regelmatig uitstapjes voor spierziektepatiënten organiseert.

Twee variabelen werden gemanipuleerd. De eerste onafhankelijke variabele was het type appeal dat gebruikt werd. In de brief met de self-benefit appeal werd benadrukt welke voordelen vrijwilligerswerk heeft voor vrijwilligers. In de brief met de other-benefit appeal werden de voordelen van vrijwilligerswerk voor de patiënten benadrukt. De voordelen waren in beide appeals inhoudelijk hetzelfde zodat hun effecten zuiver vergeleken konden worden. Onderstaande alinea uit de brief laat zien hoe de genoemde voordelen gelijk waren voor de vrijwilliger (in de self-benefit appeal) en de patiënt (in de other-benefit appeal):

Voor [vrijwilligers/patiënten] zijn deze uitstapjes vaak heel belangrijk. Ze zijn veel meer buiten dan voorheen en ontdekken leuke plaatsen en activiteiten in het land. Daarnaast ontmoeten ze tijdens de uitstapjes veel andere [vrijwilligers/patiënten] met wie vaak hechte vriendschappen ontstaan. Het Spierziekte Fonds betekent veel voor [vrijwilligers/patiënten met spierziektes]. Het ondernemen van activiteiten met [patiënten/andere patiënten] geeft hun een goed gevoel.

De tweede onafhankelijke variabele was de aan- of afwezigheid van een exemplar in de brief. In de brieven met een exemplar werd het bovenstaande fragment (de conditie zonder exemplar) vervangen door een persoonlijk verhaal.Voor de versie waarin de self-benefit appeal werd gecombineerd met een exemplar, was het verhaal van een vrijwilliger van het Spierziekte Fonds te lezen:

Het verhaal van Annette van Schinkel (35) laat zien hoe belangrijk het werk van het Spierziekte Fonds is. Annette is als vrijwilliger werkzaam bij het Spierziekte Fonds. $\mathrm{Ze}$ gaat al enkele jaren regelmatig als begeleider mee met deze uitstapjes. Voor Annette zijn deze uitstapjes heel belangrijk geworden. $Z e$ is nu veel meer buiten dan voorheen en ontdekt leuke plaatsen en activiteiten in het land. Daarnaast heeft ze tijdens de uitstapjes veel andere vrijwilligers ontmoet met wie hechte vriendschappen zijn ontstaan. Het Spierziekte Fonds betekent veel voor Annette. Het ondernemen van activiteiten met patiënten geeft haar een onbeschrijflijk goed gevoel. 
In de versie van de brief waarin de other-benefit appeal gecombineerd werd met een exemplar was hetzelfde verhaal te lezen, met als verschil dat Annette van Schinkel geïntroduceerd werd als een spierziektepatiënte die gebaat is bij de uitstapjes. Uit de exemplars bleek zo welke voordelen het vrijwilligerswerk voor de vrijwilliger (in de versie met de self-benefit appeal) respectievelijk de patiënt (in de versie met de other-benefit appeal) heeft opgeleverd. Deze voordelen waren identiek aan de voordelen die genoemd werden in de brieven zonder exemplar. Zo ontstonden vier versies van de brief: een brief met een self-benefit appeal zonder exemplar (213 woorden), een brief met een other-benefit appeal zonder exemplar (224 woorden), een brief met een self-benefit appeal en met een exemplar (255 woorden) en een brief met een other-benefit appeal en met een exemplar (287 woorden). Aan het einde van elke brief werd de lezer gevraagd vrijwilliger te worden bij het Spierziekte Fonds en werden het telefoonnummer en de website van de organisatie vermeld.

Een pretest werd uitgevoerd om de manipulatie van de twee soorten appeals te controleren. Twintig personen (75\% vrouw; 65\% student/scholier, 35\% werkend of thuisblijvend) in de leeftijd van 19 tot 58 jaar $(M=26.95, S D=10.26)$ lazen één van de twee versies van de brief zonder exemplar. Daarna beantwoordden zij vier vragen (cf. White \& Peloza, 2009) waarmee werd nagegaan in hoeverre de brief gericht was op voordeel voor anderen ("In hoeverre is de brief gericht op het helpen van anderen?" en "In hoeverre is de brief gericht op het belang van anderen?"; $r=.93$ ) en in hoeverre de brief gericht was op voordeel voor de vrijwilliger zelf ("In hoeverre is de brief gericht op het helpen van jezelf?" en "In hoeverre is de brief gericht op eigenbelang?"; $r=.87)$. Antwoorden werden gegeven op 7-punts schalen $(1=$ helemaal niet en $7=$ helemaal wel).

Er bleek een interactie-effect te zijn tussen het type appeal dat gelezen werd en het oordeel over de mate waarin de brief gericht was op voordeel voor anderen of op voordeel voor de vrijwilliger zelf $\left(F(1,18)=39.09, p<.001, \eta^{2}=.69\right)$. Personen die de brief met de other-benefit appeal lazen vonden de brief meer gericht op voordeel voor anderen $(M=$ $6.60, S D=0.52)$ dan personen die de brief met de self-benefit appeal lazen $(M=2.85, S D=$ 1.87). Personen die de brief met de self-benefit appeal lazen vonden de brief meer gericht op voordeel voor de vrijwilliger zelf $(M=5.60, S D=1.65)$ dan personen die de brief met de other-benefit appeal lazen $(M=2.15, S D=1.25)$. De manipulatie van de other-benefit appeal en de self-benefit appeal is dus succesvol gebleken.

4.2 Proefpersonen In total namen 120 proefpersonen (52.5\% vrouw) deel aan het experiment, in de leeftijd van 17 tot 81 jaar $(M=30.59, S D=16.16)$. Het merendeel van hen was student (60\%). De overige proefpersonen werkten (30.8\%), hadden tijdelijk geen werk of genoten een uitkering (5\%), waren gepensioneerd $(2.5 \%)$ of waren huisman of huisvrouw $(1.7 \%)$. Het opleidingsniveau varieerde van lager beroepsonderwijs tot wetenschappelijk onderwijs. Bijna 52\% van de proefpersonen kende een spierziektepatiënt.

Proefpersonen in de vier condities verschilden niet van elkaar in de verhouding tussen vrouwen en mannen $\left(\chi^{2}(3)=7.85, p=.05\right)$, gemiddelde leeftijd $(F(3,116)<1)$, opleidingsniveau $\left(\chi^{2}(15)=20.76, p=.15\right)$, huidige studie/werksituatie $\left(\chi^{2}(15)=10.64, p=.78\right)$, en de verhouding tussen het aantal personen dat wel of niet iemand met een spierziekte kende $\left(\chi^{2}(3)=2.27, p=.52\right)$. 
4.3 Instrumentatie De overtuigingskracht van de brief werd gemeten aan de hand van de volgende afhankelijke variabelen: de gedragsintentie, de attitude ten opzichte van vrijwilligerswerk bij de organisatie en de betrouwbaarheid van de organisatie. Daarnaast werden de waardering voor de brief en de levendigheid en begrijpelijkheid van de brief en de altruïstische persoonlijkheid van de proefpersonen gemeten. De manipulatie van de appeals werd opnieuw gecontroleerd.

Gedragsintentie

Drie verschillende gedragsintenties werden gemeten. De intentie om meer informatie over het Spierziekte Fonds in te winnen werd gemeten met twee vragen: "Hoe waarschijnlijk is het dat u na het lezen van de brief de website gaat bezoeken om meer informatie over vrijwilligerswerk bij het Spierziekte Fonds te krijgen?" en "Hoe waarschijnlijk is het dat u na het lezen van de brief het informatienummer gaat bellen om meer informatie over vrijwilligerswerk bij het Spierziekte Fonds te krijgen?” $(r=.68)$.

De intentie om vrijwilliger te worden bij het Spierziekte Fonds werd gemeten aan de hand van twee vragen (cf. Hornikx et al., 2010): "Hoe waarschijnlijk is de kans dat u na het lezen van de brief erover na zult denken om vrijwilliger te worden bij het Spierziekte Fonds?" en "Hoe waarschijnlijk is de kans dat u daadwerkelijk vrijwilliger gaat worden bij het Spierziekte Fonds na het lezen van de brief?" $(r=.69)$.

De intentie om vrijwilligerswerk bij anderen aan te bevelen werd gemeten met de vraag: "Hoe waarschijnlijk is het dat $\mathrm{u}$ na het lezen van de brief anderen zult aanraden om vrijwilliger te worden bij het Spierziekte Fonds?”. Antwoorden werden gegeven op een 7-punts schaal $(1=$ zeer onwaarschijnlijk, $7=$ zeer waarschijnlijk $)$.

Attitude ten opzichte van vrijwilligerswerk

De attitude ten opzichte van vrijwilligerswerk bij het Spierziekte Fonds werd gemeten met de stelling "Vrijwilliger worden bij het Spierziekte Fonds vind ik..." gevolgd door vier 7-punts semantische differentialen (cf. Hoeken \& Hustinx, 2007): onverstandig - verstandig; slecht - goed; onzinnig - zinnig; niet wijs - wijs $(\alpha=.84)$.

Betrouwbaarheid van de organisatie

De betrouwbaarheid van de organisatie werd gemeten met de stelling "Het Spierziekte Fonds komt op mij over als..." gevolgd door vier 7-punts semantische differentialen (cf. Hornikx et al., 2010): zeer onbetrouwbaar - zeer betrouwbaar; zeer ondeskundig - zeer deskundig; zeer onoprecht - zeer oprecht; zeer zelfzuchtig - zeer onzelfzuchtig $(\alpha=.84)$.

Met een factoranalyse is nagegaan of de componenten van overtuigingskracht (de drie gedragsintenties, de attitude ten opzichte van vrijwilligerswerk bij de organisatie en de betrouwbaarheid van de organisatie) ook daadwerkelijk als drie afzonderlijke componenten beschouwd konden worden. Een Principal Factor Analysis met varimax-rotatie liet een oplossing zien in de drie gewenste factoren (verklaarde variantie: 59.39\%; twee verwijderde items: intentie om vrijwilligerswerk bij anderen aan te bevelen, zelfzuchtigheid van de organisatie). 
Waardering voor de brief

De waardering voor de brief werd gemeten met de stelling "Ik vind de brief..." gevolgd door vijf 7-punts semantische differentialen (cf. Hornikx et al., 2010): zeer eentonig - zeer gevarieerd; zeer langdradig - zeer onderhoudend; zeer vervelend - zeer aangenaam; zeer saai - zeer interessant; zeer onprettig leesbaar - zeer prettig leesbaar $(\alpha=.83)$.

Levendigheid en begrijpelijkheid van de brief

De levendigheid en begrijpelijkheid van de brief werden gemeten met behulp van de stelling "Ik vind de brief...", gevolgd door twee 7-punts semantische differentialen: abstract levendig (levendigheid) en onbegrijpelijk - begrijpelijk (begrijpelijkheid).

Altruïstische persoonlijkheid

De altruïstische persoonlijkheid van de proefpersonen werd gemeten met tien items uit de Self-Report Altruism Scale (Rushton, Chrisjohn, \& Fekken, 1981). Voorbeelden zijn: "Ik heb geld gedoneerd aan een goed doel" en "Ik heb mijn zitplaats in een bus of trein afgestaan aan een onbekende die anders moest staan". Voor elk item konden de proefpersonen aangeven hoe vaak deze situatie in hun leven is voorgekomen (nooit, eens, meer dan eens, vaak en heel vaak). De betrouwbaarheid van de altruïsmeschaal was discutabel $(\alpha=.62)$ en kon niet worden verhoogd door verwijdering van één van de items. Met een principale componentenanalyse is nagegaan of de schaal uit verschillende dimensies bestond. De analyse liet een oplossing zien in drie factoren, maar de betrouwbaarheid van elke factor was laag $(\alpha$ 's $<.54)$. Daarom is deze schaal niet meegenomen in de analyses.

Manipulatiecheck

De manipulatie van de twee soorten appeals werd gecontroleerd met behulp van dezelfde vier 7-puntsvragen vragen die ook in de pretest zijn gebruikt (cf. White \& Peloza, 2009; brief gericht op voordelen voor anderen: $r=.78$; brief gericht op voordelen voor vrijwilliger: $r$ $=.63)$.

4.4 Procedure Proefpersonen werden individueel of in kleine groepjes in wijkcentra, treinen en op een universiteitscampus benaderd voor deelname aan het onderzoek en werden willekeurig aan één van de vier condities toegewezen. De proefpersonen lazen een korte instructie, waarop de brief volgde. Vervolgens beantwoordden zij de vragen. Ten slotte noteerden zij enkele persoonlijke gegevens (leeftijd, geslacht, nationaliteit, moedertaal, opleiding, studie-/werksituatie, aanwezigheid van spierziektepatiënten in hun sociale omgeving). Deelname aan het onderzoek verliep individueel en duurde vijf tot tien minuten.

\section{Resultaten}

5.1 Manipulatiecheck De manipulatie van de other-benefit appeal en de self-benefit appeal bleek opnieuw succesvol. Zoals in de pretest trad er een interactie-effect op tussen het type appeal dat gelezen werd en het oordeel over de mate waarin de brief gericht was op voordeel voor anderen of op voordeel voor de vrijwilliger zelf $\left(F(1,118)=32.58, p<.001, \eta^{2}\right.$ $=.22$ ). Proefpersonen die een brief met de other-benefit appeal lazen vonden de brief meer gericht op voordeel voor anderen $(M=5.87, S D=0.99)$ dan proefpersonen die een brief 
met de self-benefit appeal lazen $(M=4.89, S D=1.52)$. Proefpersonen die een brief met de self-benefit appeal lazen vonden de brief meer gericht op voordeel voor de vrijwilliger zelf $(M=4.07, S D=1.72)$ dan proefpersonen die een brief met de other-benefit appeal lazen $(M$ $=2.68, S D=1.08)$.

Proefpersonen die een brief met de self-benefit appeal lazen scoorden dus ook hoog $(M$ $=4.89$ ) op het oordeel over de mate waarin de brief gericht was op voordeel voor anderen. Deze score is in het genre van wervingsbrieven niet verwonderlijk, aangezien het helpen van anderen inherent is aan het verrichten van vrijwilligerswerk (vrijwilligerswerk levert nooit alleen maar voordelen voor de vrijwilliger zelf op). Van belang voor het huidige onderzoek is dat de oordelen over de voordelen voor anderen en de voordelen voor de vrijwilliger verschilden tussen de condities: de other-benefit appeal leidde in vergelijking met de self-benefit appeal tot een hoger oordeel over de mate waarin de brief gericht was op voordeel voor anderen; de self-benefit appeal leidde in vergelijking met de other-benefit appeal tot een hoger oordeel over de mate waarin de brief gericht was op voordeel voor de vrijwilliger zelf.

5.2 Onderzoeksvragen Onderzoeksvraag 1 had betrekking op de effecten van self-benefit appeals en other-benefit appeals op de overtuigingskracht van wervingsbrieven. Uit een multivariate variantieanalyse met de drie componenten voor overtuigingskracht bleek een hoofdeffect van type appeal op de overtuigingskracht van de brief $\left(F(3,114)=5.82, p<.01, \eta^{2}=\right.$ .13). Dit effect werd voor alle drie de afhankelijke variabelen gevonden. De gemiddeldes en standaardafwijkingen zijn weergegeven in tabel 2.

Tabel 2: Gedragsintentie, attitude t.o.v. vrijwilligerswerk en betrouwbaarheid van de organisatie en als functie van het type appeal en de aan- of afwezigheid van een exemplar ( $n=30$ per conditie, $1=$ negatief, $7=$ positief)

\begin{tabular}{lcccccccc}
\hline & \multicolumn{3}{c}{$\begin{array}{c}\text { Self-benefit appeal } \\
\text { + exemplar }\end{array}$} & \multicolumn{3}{c}{ - exemplar } & Other-benefit appeal \\
& $M$ & $S D$ & $M$ & $S D$ & $M$ & $S D$ & $M$ & $S D$ \\
\hline & 1.96 & 0.98 & 2.03 & 1.03 & 2.48 & 1.06 & 2.31 & 0.89 \\
\hline Gedragsintentie & 5.45 & 1.40 & 5.11 & 1.19 & 5.77 & 0.94 & 5.86 & 0.88 \\
Attitude t.o.v. vrijwilligerswerk & 5.02 & 1.01 & 4.52 & 1.29 & 5.53 & 0.83 & 5.40 & 1.10 \\
Betrouwbaarheid organisatie & & & & & & &
\end{tabular}

Het type appeal had een effect op de gedragsintentie van de proefpersonen $(F(1,116)=4.89$, $\left.p<.05, \eta^{2}=.04\right)$. Zoals uit tabel 2 blijkt, hadden proefpersonen die een brief met de otherbenefit appeal lazen $(M=2.39, S D=0.97)$ een positievere gedragsintentie dan proefpersonen die een brief met de self-benefit appeal lazen $(M=1.99, S D=1.00)$. Er werd tevens een effect gevonden van type appeal op de attitude van de lezer ten opzichte van vrijwilligerswerk bij de organisatie $\left(F(1,116)=6.73, p<.05, \eta^{2}=.06\right)$. Tabel 2 laat zien dat proefpersonen die de other-benefit appeal lazen $(M=5.81, S D=0.91)$ een positievere attitude ten opzichte van vrijwilligerswerk hadden dan proefpersonen die de self-benefit appeal lazen $(M=5.28, S D=$ 1.30). Ook op de betrouwbaarheid van de organisatie werd een effect gevonden van type appeal $\left(F(1,116)=12.64, p<.01, \eta^{2}=.10\right)$. Proefpersonen die een other-benefit appeal lazen $(M=5.47, S D=0.97)$ vonden de organisatie betrouwbaarder dan proefpersonen die een self-benefit appeal lazen $(M=4.77, S D=1.17)$. 
Onderzoeksvraag 2 had betrekking op de overtuigingskracht van exemplars in wervingsbrieven. Er bleek geen hoofdeffect van exemplar op de overtuigingskracht van de brief te zijn $(F(3,114)<1)$. Er was ook geen interactie-effect tussen exemplar en type appeal op de overtuigingskracht van de brief $(F(3,114<1)$.

5.3 Toetsing van de hypotheses Hypothese 1 voorspelde dat wervingsbrieven met een exemplar beter zouden worden gewaardeerd dan wervingsbrieven zonder exemplar en hypothese 2 voorspelde dat levendigheid en begrijpelijkheid dit effect zouden kunnen verklaren. Een mediatie-analyse werd uitgevoerd om deze hypotheses te toetsen, waarbij de techniek voor mediatie-analyse met meerdere mediërende variabelen zoals beschreven in Preacher en Hayes (2008) werd gehanteerd.

Eerst werden de voorspellende relaties tussen de variabelen getoetst. Drie regressie-analyses met de aanwezigheid van een exemplar als dummyvariabele werden uitgevoerd. De aanwezigheid van een exemplar was een significante positieve voorspeller van de waardering voor de brief $(B=0.47, t=2.22, p<.05)$. Hypothese 1 is daarmee bevestigd. De exemplar verhoogde tevens de begrijpelijkheid van de brief $(B=0.62, t=2.57, p<.05)$ en de levendigheid van de brief $(B=0.71, t=3.46, p<.001)$.Vervolgens werden twee regressie-analyses uitgevoerd om de relaties tussen begrijpelijkheid en waardering voor de brief en tussen levendigheid en waardering voor de brief te toetsen. De begrijpelijkheid en de levendigheid van de brief bleken allebei significante voorspellers van de waardering voor de brief te zijn (begrijpelijkheid: $B=0.30, t=4.52, p<.001$; levendigheid: $B=0.47, t=6.13, p<.001$ ). De mediatie-analyse toonde vervolgens aan dat de aan- of afwezigheid van een exemplar geen effect meer had op de waardering voor de brief indien gecontroleerd werd voor de begrijpelijkheid en de levendigheid van de brief $(B=-0.05, t=0.31, p=.76)$.

De indirecte effecten van de exemplar op de waardering voor de brief via levendigheid en begrijpelijkheid werden getoetst met behulp van de Sobel (1982) toets. Deze toets liet zien dat het indirecte effect van de exemplar op de waardering voor de brief via de mediërende variabele begrijpelijkheid significant was $(z=2.25, p<.05)$. Ook het indirecte effect van de exemplar op de waardering voor de brief via de mediërende variabele levendigheid bleek significant te zijn $(z=3.03, p<.01)$. Hiermee is angetoond dat het effect van de exemplar op de waardering voor de brief volledig gemedieerd wordt door begrijpelijkheid en levendigheid. Hypothese 2 is dus bevestigd. In figuur 1 zijn de relaties tussen de variabelen weergegeven.

\section{Conclusie en discussie}

6.1 Appeals Met een experiment werden de effecten van self-benefit appeals en other-benefit appeals op de overtuigingskracht van wervingsbrieven op een zuivere manier met elkaar vergeleken. Waar in eerder onderzoek de voordelen van een donatie in de gemanipuleerde self-benefit appeal en other-benefit appeal vaak inhoudelijk van elkaar verschilden, werden de voordelen in het huidige onderzoek in beide appeals gelijkgehouden. Uit de resultaten bleek dat de other-benefit appeal overtuigender was dan de self-benefit appeal.Vergeleken met een selfbenefit appeal leidde een other-benefit appeal tot een positievere gedragsintentie, een positievere attitude ten opzichte van vrijwilligerswerk bij de organisatie en een grotere betrouwbaarheid van de organisatie. Dit laatste resultaat sluit aan bij het onderzoek van Hornikx et al. 


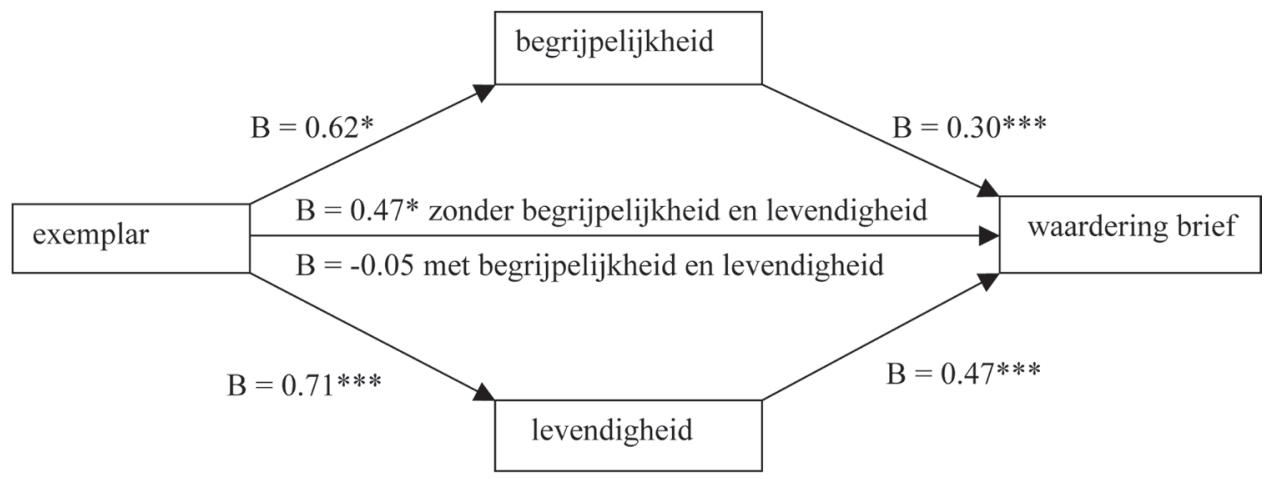

Figuur 1: Begrijpelijkheid en levendigheid als mediërende variabelen tussen exemplar en waardering voor de brief $\left({ }^{\star} p<.05\right.$, $\star \star \star p<.001)$

(2010), waarin de proefpersonen de organisatie ook betrouwbaarder vonden na het lezen van een other-benefit appeal dan na het lezen van een self-benefit appeal. Het huidige onderzoek versterkt deze bevinding bovendien door het te repliceren middels een zuivere vergelijking tussen de twee soorten appeals.

De resultaten van het onderzoek vinden aansluiting bij de empathy-altruism-hypothese (Batson et al., 1981), die stelt dat het hulpgedrag van mensen voortkomt uit altruïstische motieven. Een other-benefit appeal wijst de lezer op de mogelijkheid zijn gevoelens van empathie voor een ander om te zetten in hulpgedrag. Een self-benefit appeal daarentegen wijst de lezer erop dat hij of zij zelf voordeel zal hebben bij een donatie en speelt op die manier in op egoïstische motieven.Vanuit de Social Exchange Theory (Blau, 1964) beredeneerd zou dit type appeal overtuigender moeten zijn dan een other-benefit appeal, omdat mensen volgens deze theorie hulp bieden teneinde daar zelf voordeel uit te halen. Hoewel het huidige onderzoek laat zien dat in deze wervingsbrief other-benefit appeals overtuigender zijn dan self-benefit appeals, geeft het geen uitsluitsel over de daadwerkelijke motieven die ten grondslag liggen aan het hulpgedrag van mensen. Het is evenwel mogelijk dat hulpgedrag gedreven wordt door egoïstische motieven, maar dat mensen daar niet expliciet aan herinnerd willen worden of dat ze het om sociaal wenselijke redenen willen doen voorkomen dat zij hulp zouden bieden uit altruïstische overwegingen (vergelijk White \& Peloza, 2009).

6.2 Exemplars In het huidige onderzoek werden wervingsbrieven met een exemplar vergeleken met wervingsbrieven zonder exemplar. In voorgaande onderzoeken waarin effecten van exemplars in persuasieve teksten op de overtuigingen, attitude en intentie van de lezer gerapporteerd zijn, werden telkens twee verschillende exemplars met elkaar vergeleken zonder dat er sprake was van een controleconditie zonder exemplar (Hoeken \& Hustinx, 2007; Jansen et al., 2005). Met de opzet van het huidige onderzoek kon de effectiviteit van een exemplar op zich vastgesteld worden. De aanwezigheid van een exemplar bleek geen invloed te hebben op de overtuigingskracht van de wervingsbrief. De manipulatie van de exemplar biedt hiervoor een mogelijke verklaring. De exemplars waren kort en bevatten niet veel (emotionele) details over de hoofdpersoon, waardoor de exemplars mogelijk geen kans hebben gehad de lezer te beïnvloeden. Meer onderzoek is dan ook wenselijk om de effectiviteit van exemplars 
in kaart te brengen en na te gaan welke specifieke eigenschappen van deze voorbeeldverhalen tot welke effecten leiden.

De brieven met een exemplar werden wel beter gewaardeerd dan de brieven zonder exemplar. Met een mediatie-analyse is aangetoond dat het effect van een exemplar op de waardering voor de brief volledig verklaard kan worden door de begrijpelijkheid en levendigheid van de brief. Deze bevinding vindt aansluiting bij theorieën over de waardering voor concrete informatie (Sadoski et al., 2000), zoals de informatie in exemplars, en de begrijpelijkheid en levendigheid van exemplars (Brosius, 1999; Hinnant et al., 2012). Gezien de eenvoudige aard van de manipulatie zijn de effecten van de exemplar op de lezer opmerkelijk te noemen. In de brieven met en zonder exemplar werd inhoudelijk dezelfde informatie geboden. Het verschil tussen de brieven bestond erin dat in de brief zonder exemplar de voordelen van vrijwilligerswerk werden toegekend aan een groep (patiënten of vrijwilligers), waar deze zelfde voordelen in de brief met een exemplar werden toegekend aan een specifieke persoon (patiënt of vrijwilliger). Enkel het noemen van een persoon als voorbeeld blijkt een hele brief dus al begrijpelijker en levendiger voor de lezer te kunnen maken. Hoewel exemplars niet bijdragen aan de verwezenlijking van het daadwerkelijke doel van wervingsbrieven, namelijk het overtuigen van de lezer, is het gebruik van dit soort voorbeeldverhalen dan ook aan te raden aan organisaties die willen inzetten op begrijpelijke en levendige brieven, om op die manier bovendien de waardering voor de wervingsbrieven te verhogen.

6.3 Vervolgonderzoek De scores op de gedragsintentie van de lezer bleven in alle condities beneden het neutrale middelpunt van de schaal. Dit roept de vraag op of het doel van de brief wel is bereikt: was de wervingsbrief ook daadwerkelijk wervend? De intentiescore is weliswaar laag, maar er zijn drie geruststellende gedachten. In de eerste plaats zijn de scores op de attitude ten opzichte van vrijwilligerswerk en op de betrouwbaarheid van de organisatie rond de 4.5-5.5 op een 7-puntsschaal. Als ook deze scores laag zouden zijn geweest, dan was dit een sterke aanwijzing geweest voor de stelling dat de brief zijn doel niet heeft bereikt. In de tweede plaats werkt de intentiemaat: er is een hoofdeffect van appeal gevonden op intentie. Dat betekent dat de score niet zo laag is dat variatie in de brief geen effect meer kan uitoefenen. In de derde plaats is een lage intentiescore niet verwonderlijk: vrijwilliger worden is een keuze die consequenties voor de lange termijn met zich meebrengt. Volgens gedragsvoorspellende theorieën en modellen als de Theory of Reasoned Action (Fishbein \& Ajzen, 1975; Ajzen \& Fishbein, 1980) en het Integrative Model of Behavioral Prediction (Fishbein \&Yzer, 2003) wordt de intentie om dergelijk gedrag te vertonen direct en indirect beïnvloed door verschillende variabelen, zoals de waargenomen sociale norm, overtuigingen over het kunnen uitvoeren van het gedrag en demografische variabelen. De lage intentiescores uit het huidige onderzoek duiden erop dat een tekst alleen niet genoeg is om een positieve intentie bij de lezer te bereiken; er zijn immers tal van aspecten die het vormen van een positieve intentie kunnen belemmeren.

Met het oog op de lage intentiescores en het belang van het meten van intentie voor wervingsbrieven zou het voor vervolgonderzoek van belang zijn om ook een kwalitatieve vraag te stellen over de intentie om vrijwilliger te worden. Met open vragen over de motieven van de proefpersonen om wel of juist niet vrijwilliger te worden kan rechtstreeks worden nagegaan welke altruïstische en egoïstische motieven bij de proefpersonen een rol spelen. Door de motieven die proefpersonen aandragen te coderen kan inzicht ontstaan in hun beweegredenen. Deze maat geeft daarom wellicht meer informatie dan alleen de ge- 
middelde (lage) intentiescore die nu uit de resultaten naar voren kwam.

In dit onderzoek is de relatieve effectiviteit van self-benefit appeals en other-benefit appeals alleen onderzocht in een brief gericht op het werven van vrijwilligers. Om een vollediger beeld te krijgen van de relatieve effectiviteit van de twee soorten appeals is vervolgonderzoek nodig met brieven waarin de lezer wordt opgeroepen tot andere soorten donaties, zoals bloed, geld of kleding. In het huidige onderzoek is ook niet gekeken naar de effectiviteit van een combinatie van self-benefit appeals en other-benefit appeals. Hoewel een dergelijke combinatie intuïtief effectief lijkt, heeft een reeks experimenten aangetoond dat het samenvoegen van altruïstische en egoïstische redenen om te doneren juist minder overtuigend is dan het noemen van enkel een of meerdere altruïstische redenen of enkel een of meerdere egoïstische redenen (Feiler, Tost, \& Grant, 2012). De verklaring hiervoor is dat een combinatie van appeals de lezer er nadrukkelijk op wijst dat er sprake is van een poging tot overtuigen, hetgeen tot weerstand leidt. In het onderzoek van Feiler et al. (2012) werd aan de proefpersonen gevraagd geld te doneren. Het is nog onduidelijk wat de effecten van een combinatie van appeals is in brieven gericht op het werven van vrijwilligers. Zeker omdat er aanwijzingen zijn dat mensen vrijwilligerswerk verrichten om zowel altruïstische als egoïstische redenen (Clary \& Snyder, 1999), biedt een vergelijking tussen een combinatie van appeals enerzijds en een self-benefit appeal of other-benefit appeal anderzijds een waardevolle mogelijkheid voor vervolgonderzoek.

\section{Bibliografie}

Ajzen, I., \& Fishbein, M. (1980). Understanding attitudes and predicting social behavior. Englewood Cliffs, NJ: Prentice Hall.

Aust, C.F., \& Zillmann, D. (1996). Effects of victim exemplification in television news on viewer perception of social issues. Journalism and Mass Communication Quarterly, 73, 787-803.

Batson, C.D., Duncan, B.D., Ackerman, P., Buckley, T., \& Birch, K. (1981). Is empathic emotion a source of altruistic motivation? Journal of Personality and Social Psychology, 40, 290-302.

Batson, C.D., Dyck, J.L., Brandt, J.R., Batson, J.G., Powell, A.L., McMaster, M.R., \& Griffitt, C. (1988). Five studies testing two new egoistic alternatives to the empathy-altruism hypothesis. Journal of Personality and Social Psychology, 55, 52-77.

Batson, C.D. (1990). How social an animal? The human capacity for caring. American Psychologist, 45, 336-346.

Batson, C.D., Batson, J.G., Slingsby, J.K., Harrell, K.L., Peekna, H.M., \& Todd, R.M. (1991). Empathic joy and the empathy-altruism hypothesis. Journal of Personality and Social Psychology, 61, 413-426.

Blau, P.M. (1964). Exchange and power in social life. New York: John Wiley \& Sons.

Brosius, H. (1999). The influence of exemplars on recipients' judgements: The part played by similarity between exemplar and recipient. European Journal of Communication, 213-224.

Brunel, F.F., \& Nelson, M.R. (2000). Explaining gendered responses to "help-self" and "help-others" charity ad appeals: The mediating role of world-views. Journal of Advertising, 29, 15-28.

Clary, E.G., \& Snyder, M. (1999). The motivations to volunteer: Theoretical and practical considerations. Current Directions in Psychological Science, 8, 156-159.

Eckel, C.C., \& Grossman, P.J. (1996). Altruism in anonymous dictator games. Games and Economic Behavior, 16 , 181-191.

Feiler, D.C., Post, L.P., \& Grant, A.M. (2012). Mixed reasons, missed givings: The costs of blending egoistic and altruistic reasons in donation requests. Journal of Experimental Social Psychology, 48, 1322-1328. 
Ferguson, E., Farrell, K., \& Lawrence, C. (2008). Blood donation is an act of benevolence rather than altruism. Health Psychology, 27, 327-336.

Fishbein, M., \& Ajzen, I. (1975). Belief, attitude, intention, and behavior: An introduction to theory and research. Reading, MA: Addison-Wesley.

Fishbein, M., \& Yzer, M.C. (2003). Using theory to design effective health behavior interventions. Communication Theory, 13, 164-183.

Fisher, R.J., Vandenbosch, M., \& Antia, K.D. (2008). An empathy-helping perspective on consumers' responses to fund-raising appeals. Journal of Consumer Research, 35, 519-531.

Gibson, R., \& Zillmann, D. (1994). Exaggerated versus representative exemplification in news reports: Perception of issues and personal consequences. Communication Research, 21, 603-624.

Handy, F., Cnaan, R.A., Brudney, J.L., Ascoli, U., Meijs, L.C., \& Ranade, S. (2000). Public perception of "who is a volunteer": An examination of the net-cost approach from a cross-cultural perspective. International Journal of Voluntary and Nonprofit Organizations, 11, 45-65.

Hinnant, A., Len-Ríos, M.E., \& Young, R. (2012). Journalistic use of exemplars to humanize health news. Journalism Studies. DOI: 10.1080/1461670X.2012.721633

Hoeken, H., \& Hustinx, L. (2007). The impact of exemplars on responsibility stereotypes in fund-raising letters. Communication Research, 34, 596-617.

Holmes, J.G., Miller, D.T., \& Lerner, M.J. (2002). Committing altruism under the cloak of self-interest: The exchange fiction. Journal of Experimental Social Psychology, 38, 144-151.

Hornikx, J. (2005). A review of experimental research on the relative persuasiveness of anecdotal, statistical, causal, and expert evidence. Studies in Communication Sciences, 5, 205-216.

Hornikx, J. (2007). Is anecdotal evidence more persuasive than statistical evidence? A comment on classic cognitive psychological studies. Studies in Communication Sciences, 7, 151-164.

Hornikx, J., Hendriks, B., \& Thijzen, D. (2010). The effects of cultural adaptation in fundraising letters: The case of help-self and help-others appeals in a feminine culture. Communications, 34, 93-110.

Hupfer, M.E. (2006). Helping me, helping you: Self-referencing and gender roles in donor advertising. Transfusion, 46, 996-1005.

Jansen, C., Croonen, M., \& De Stadler, L. (2005). 'Take John, for instance'. Effects of exemplars in public information documents on HIV/AIDS in South Africa. Information Design Journal + Document Design, 13, 194-210.

Kahneman, D. (2003). A perspective on judgment and choice: Mapping bounded rationality. American Psychologist, 58, 697-720.

Landry, C., Lange, A., List, J.A., Price, M.K., \& Rupp, N.G. (2006). Toward an understanding of the economics of charity: Evidence from a field experiment. Quarterly Journal of Economics, 121, 747-782.

Nelson, R.M., Brunel, F.F., Supphellen, M., \& Manchanda, R.V. (2006). Effects of culture, gender, and moral obligations on responses to charity advertising across masculine and feminine cultures. Journal of Consumer Psychology, $16,45-56$.

Neuendorf, K.A. (2002). The content analysis guidebook. Thousand Oaks, CA: Sage Publications.

Oliver, M.B., Dillard, J.P., Bae, K., \& Tamul, D.J. (2012). The effect of narrative news format on empathy for stigmatized groups. Journalism and Mass Communication Quarterly, 89, 205-224.

Piliavin, J.A., \& Charng, H. (1990). Altruism: A review of recent theory and research. Annual Review of Sociology, 16, 27-65.

Preacher, K.J., \& Hayes, A.F. (2008). Asymptotic and resampling strategies for assessing and comparing indirect effects in multiple mediator models. Behavior Research Methods, 40, 879-891.

Rushton, J.P, Chrisjohn, R.D., \& Fekken, C. (1981). The altruistic personality and the self-report altruism scale. Personality and Individual Differences, 2, 293-302. 


\section{Kobie van Krieken en Jos Hornikx}

Sadoski, M., Goetz, E.T., \& Rodriguez, M. (2000). Engaging texts: Effects of concreteness on comprehensibility, interest, and recall in four text types. Journal of Educational Psychology, 92, 85-95.

Sobel, M.E. (1982). Asymptotic confidence intervals for indirect effects in structural equation models. In S. Leinhardt (Red.), Sociological methodology (pp. 290-312). Washington, DC: American Sociological Association.

Unger, L.S. (1991). Altruism as a motivation to volunteer. Journal of Economic Psychology, 12, 71-100.

White, K., \& Peloza, J. (2009). Self-benefit versus other-benefit marketing appeals: Their effectiveness in generating charitable support. Journal of Marketing, 73, 109-124.

Wilson, J. (2000). Volunteering. Annual Review of Sociology, 26, 215-240.

Zillmann, D., \& Brosius, H.B. (2000). Exemplification in communication: The influence of case reports on the perception of issues. Mahwah, NJ: Lawrence Erlbaum Associates.

Zillmann, D. (2006). Exemplification effects in the promotion of safety and health. Journal of Communication, 56, S221-S237. 
Bijlage 1 Brief met other-benefit appeal zonder exemplaar

Den Haag, 10 september 2011

Geachte heer, mevrouw,

Het Spierziekte Fonds zet zich in voor meer dan $\mathbf{2 0 0 . 0 0 0 ~ m e n s e n ~ i n ~ N e d e r l a n d ~ d i e ~ l i j d e n ~}$ aan ziektes die de spieren aantasten, zoals Duchenne, Parkinson, MS, Polio en spasticiteit. U kunt ons hierbij helpen. Met uw hulp maakt $\mathbf{u}$ het leven van anderen namelijk een stukje aangenamer.

Het Spierziekte Fonds organiseert, in samenwerking met professionele zorgverleners en enthousiaste vrijwilligers, regelmatig uitstapjes voor patiënten met een spierziekte. Tijdens deze dagen worden activiteiten georganiseerd waaraan alle patiënten onbelemmerd kunnen meedoen.

Voor patiënten zijn deze uitstapjes vaak heel belangrijk. Ze zijn veel meer buiten dan voorheen en ontdekken leuke plaatsen en activiteiten in het land. Daarnaast ontmoeten ze tijdens de uitstapjes veel andere patiënten met wie vaak hechte vriendschappen ontstaan. Het Spierziekte Fonds betekent veel voor patiënten met spierziektes. Het ondernemen van activiteiten met andere patiënten geeft hun een goed gevoel.

Door uw tijd te doneren aan het Spierziekte Fonds maakt u het leven van patiënten met een spierziekte een stukje aangenamer. Er is geen betere manier om de patiënten een mooie tijd te bezorgen. Zonder vrijwilligers kunnen de uitstapjes niet blijven bestaan. Helpt $\mathrm{u}$ ons dus alstublieft en word vrijwilliger.

Kijk op www.spierziektefonds.nl of bel 0800-12111 (gratis) voor meer informatie of om u aan te melden als vrijwilliger. Bij voorbaat dank.

Met vriendelijke groeten,

Jan Dijkstra

Directeur Spierziekte Fonds 